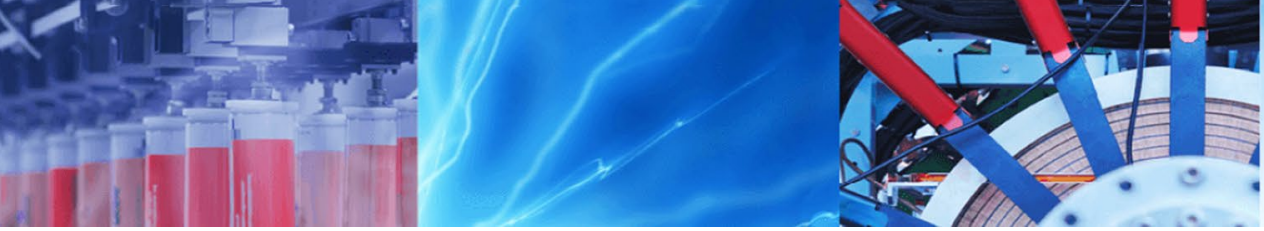

Editorial

\title{
Environmental change, resilience, adaptation and sustainability in Africa
}

\author{
Terence Epule Epule ${ }^{1}$
}

Accepted: 9 December 2021

Published online: 20 December 2021

(c) The Author(s) 2021 OPEN

Environmental changes and associated impacts are among the greatest obstacles to attaining sustainable development goals in Africa. For example, Africa is vulnerable to risks posed by climate change stressors such as increasing temperature, precipitation variability, and exposure to other stressors such as winds or sandstorms, pests, and diseases [2]. To render things worse and daunting, the continent has a limited adaptive capacity to the impacts of climate change [3]. Though this area of research is gaining much attention, before this topical collection, major knowledge gaps still existed in establishing an understanding of the socio-economic, environmental, food systems related implications of the observed changes and how they are related to current levels of resilience and vulnerability of most African environmental systems. Some major gaps the papers published in this topical collection have filled.

This topical collection has published research within the realm of regional, national, and local environmental changes and associated impacts. It has indeed enhanced the knowledge of the scientific community and provided valuable information that can be used by policymakers to formulate adaptation measures that are evidence-based and aimed at improving the resilience of different sectors. This topical collection has a total of 16 peer review papers dwelling on key themes related to environmental change, resilience, adaptation, and sustainability in Africa. These themes are of great importance in the continent of Africa because even though Africa is least responsible for climate change through low greenhouse gas emissions when compared to other parts of the world [10], the continent is the most vulnerable, least resilient, and adaptable [6].

It has been argued that resilience, vulnerability, exposure, sensitivity and the adaptive capacity of environmental systems in Africa will continue to play a key role in determining how the continent responds to climate forcing [3]. Therefore, future outcomes will be shaped by the exposure of environmental systems to changes in temperature and precipitation, historical changes in the sensitivity of crop yields and most importantly by the level of adaptive capacity of the people involved, in most cases smallholder farmers [3]. It has even been argued that the magnitude of the effects that climate change will have on a population will depend greatly on the ability to adapt as illustrated in the adaptive capacity which in turn establishes resilience [1]. Hence, it is pertinent to establish this close-knit relationship between climate on the one hand and adaptation, adaptive capacity and resilience in Africa as the continent remains highly vulnerable.

Consequently, this topical collection does indeed reflect these topics as the 16 papers published focus on themes such as vulnerability (exposure, sensitivity, and adaptive capacity) of cropping systems to droughts and crop yield gaps in Uganda, East Africa, the effects of aerosols on precipitation in central Africa, livestock and the drivers of climate variability as well as aspects of precipitation distribution over Morocco. A common observation in this topical collection is the link established by most authors to agricultural systems. Invariably, this is not unexpected as agriculture remains the "backbone" of most African

Terence Epule Epule, epule.terence@um6p.ma| ${ }^{1}$ International Water Research Institute, Mohammed 6 Polytechnic University, Lot 660, Hay Moulay Rachid, 43150 Ben Guerir, Morocco.

SN Applied Sciences $\quad$ (2022) 4:28 $\quad$ https://doi.org/10.1007/s42452-021-04920-x 
economies and therefore remains a veritable engine for establishing resilience and for development in Africa [5].

One way of going about this is through a better understanding of the relationship between yield and precipitation gaps. An approach that enables researchers to better understand where gaps exist in the yields of their crops and how these align with precipitation gaps and other possible drivers of yield $[4,7,9]$. This approach does not only inform us of the deficits in the outputs of our production systems as depicted in the relationship between actual and projected yields and actual and projected precipitation but also provides an opportunity for stakeholders to better understand the links between yield and precipitation as well as establish the role of other potential drivers of resilience in cropping systems. In Africa, the annual growth rate in agricultural production is projected to decline from 3.0 to $2.1 \%$ for the period 2006-2050 [8]. The repercussions of this decline are more daunting on smallholder farmers who constitute about $70 \%$ of the farming population [7]. In this regard, a new comprehensive research program (pan Moroccan platform for crop Yields/Precipitation Gaps, Crop Calendars for Maize, Barley, Sorghum and Beans) is focused on advancing our understanding of these issues and providing policy-relevant information to policymakers.

\section{Declarations}

Conflict of interest The author(s) declare that they have no competing interests.

Open Access This article is licensed under a Creative Commons Attribution 4.0 International License, which permits use, sharing, adaptation, distribution and reproduction in any medium or format, as long as you give appropriate credit to the original author(s) and the source, provide a link to the Creative Commons licence, and indicate if changes were made. The images or other third party material in this article are included in the article's Creative Commons licence, unless indicated otherwise in a credit line to the material. If material is not included in the article's Creative Commons licence and your intended use is not permitted by statutory regulation or exceeds the permitted use, you will need to obtain permission directly from the copyright holder. To view a copy of this licence, visit http://creativecommons. org/licenses/by/4.0/.

\section{References}

1. Adger WN, Vincent $\mathrm{K}$ (2005) Uncertainty in adaptive capacity. CR Geosci 337(4):399-410

2. Ahmadalipour A, Moradkhani H (2018) Multi-dimensional assessment of drought vulnerability in Africa: 1960-2100. Sci Total Environ 644:520-535

3. Brooks N, Adger WN, Kelly PM (2005) The determinants of vulnerability and adaptive capacity at the national level and the implications for adaptation. Glob Environ Change 15(2):151-163

4. Bregaglio S, Frasso N, Pagani V, Stella T, Francone C, Cappelli $G$ et al (2015) New multi-model approach gives good estimations of wheat yield under semi-arid climate in Morocco. Agron Sustain Dev 35(1):157-167

5. Coker AA, Audu MK (2015) Agricultural micro-credit repayment performance: evidence from Minna Microfinance bank, Nigeria. Afr J Agric Res 10(9):877-885

6. Gnonlonfoun I, Assogbadjo AE, Gnanglè CP, Kakaï RLG (2019) New indicators of vulnerability and resilience of agroforestry systems to climate change in West Africa. Agron Sustain Dev 39(2):1-12

7. Pala M, Oweis T, Benli B, De Pauw E, El Mourid M, Karrou M et al (2011) Assessment of wheat yield gap in the Mediterranean: case studies from Morocco, Syria and Turkey. International Center for Agricultural Research in the Dry Areas (ICARDA), Aleppo, Syria, IV, pp 963-1021

8. Pradhan $P$, Fischer $G$, van Velthuizen $H$, Reusser DE, Kropp JP (2015) Closing yield gaps: how sustainable can we be? PLoS ONE 10(6):e0129487

9. Saidi A, Diouri M (2017) Food self-sufficiency under the GreenMorocco Plan. J Exp Biol Agric Sci 5(1):33-40

10. Tongwane MI, Moeletsi ME (2018) A review of greenhouse gas emissions from the agriculture sector in Africa. Agric Syst 166:124-134

Publisher's Note Springer Nature remains neutral with regard to jurisdictional claims in published maps and institutional affiliations. 